\title{
The Influence of Various N-P-K Fertilizer Levels on Onion Production in Southern Puerto Rico ${ }^{1}$
}

\author{
S. Alers-Alers, E. Orengo-Santiago, and L. Cruz Pérez² \\ ABSTRACT
}

An experiment was conducted on a San Antón (Cumulic Hasplustolls) fine loamy mixed isohyperthermic in the southern irrigated coastal plain of Puerto Rico, to evaluate the influence of various N-P-K levels on yield and quality of onion (cultivar Texas Grano 502). All P and K fertilizer were broadcast and mixed with the soil at planting. Half of the $\mathrm{N}$ fertilizer was broadcast at planting and half was banded 6 weeks later between rows and left uncovered.

Mean yield differences attributable to fertilizer levels were not significant. The soil seems to have sufficient available native $\mathrm{N}$ to meet this crop's needs. This may be in part attributable to continuous fertilizer applications over the years for sugarcane production in this soil.

An average onion production of 22 metric tons/ha was obtained. The world average production is 11 metric tons/ha. Based on the results obtained, the production of onions in this soil is recommended for two reasons: 1) The high tonnage that can be obtained, and 2) the low investment on fertilizers if planted on soils of high fertility, especially if previously used for sugarcane and fertilized over a long period.

\section{INTRODUCTION}

Onions are a worldwide popular vegetable crop. Among all horticultural crops, only tomatoes are produced in larger quantities than onions. In 1974, 16 million metric tons of cured onions were produced on 1.5 millions hectares around the world. (5). The world average yield is 11 metric tons/ ha, but in lowland areas more than 36.5 metric tons/ha can be obtained. In the United States, the average production is 8.1 metric tons/ha (4).

During 1968-69 only 3.3 metric tons of onions were locally produced (2) while 9,324 metric tons were imported from United States and additional quantities from the Dominican Republic and other countries for a total consumption of 10,670 metric tons.

During 1973-74 (2), total imports of onion amounted to 10,670 metric tons with a value of $\$ 2.5$ million. These data led to the exploration of the possibilities of increasing local production. A research program on fertilizer management practices might help to enhance onion production. Good yields have been reported, and knowledge on high-yielding varieties is available in Puerto Rico. Childers et al., 1950, recommended the Bermuda types and Louisiana Red Creole as the best onion varieties for Puerto

${ }^{1}$ Manuscript submitted to editorial Board April 6, 1978

${ }^{2}$ Associate Agronomist, Research Assistant, and Director, Agronomy and Soils Department and Professor, respectively, Agricultural Experiment Station, Mayagüez Campus, University of Puerto Rico, Mayagüez, Puerto Rico. The authors acknowledge the cooperation of Dr. M. A. Lugo-López, for his assistance in preparing this article. 
Rico, for fall planting (1). Other agronomists have been working with this crop in Puerto Rico, mainly on screening of varieties (6).

This paper reports on research with various levels of N-P-K, as they influence onion yield and quality in southern Puerto Rico.

\section{MATERIALS AND METHODS}

A field experiment was established at the Fortuna Substation farm in southern Puerto Rico, to study the influence of several N-P-K fertilizer

TABLE 1.-Leaf nutrients percent from samples taken at the second and fourth months during crop cycle

\begin{tabular}{|c|c|c|c|c|c|c|c|c|c|c|}
\hline \multicolumn{3}{|c|}{ Fertilizer levels } & \multicolumn{3}{|c|}{$\begin{array}{l}\text { Leaf samples taken at } 2 \\
\text { months after been fertil- } \\
\text { ized }\end{array}$} & \multicolumn{3}{|c|}{$\begin{array}{c}\text { Leaf samples taken at } 4 \\
\text { months or date of har- } \\
\text { vest }\end{array}$} & \multirow[t]{2}{*}{ Yield } & \multirow[t]{2}{*}{$\begin{array}{c}\text { Top-bult } \\
\text { ratio }\end{array}$} \\
\hline$N$ & $\mathrm{P}_{2} \mathrm{O}_{4}$ & $\mathrm{~K}_{2} \mathrm{O}$ & $\mathrm{N}$ & $\mathrm{P}$ & $\mathrm{K}$ & $\mathrm{N}$ & $P$ & $\mathrm{~K}$ & & \\
\hline $\mathrm{Kg} / \mathrm{ha}$ & $K g / h \alpha$ & $K g / h a$ & $\%$ & $\%$ & $\%$ & $\%$ & $\%$ & $\%$ & t/ha & $\%$ \\
\hline 0 & 0 & 0 & 3.54 & .49 & 7.61 & 2.42 & 0.17 & 4.44 & 22.0 & 2.50 \\
\hline 0 & 448 & 224 & 3.52 & 0.60 & 7.64 & 2.32 & 0.17 & 4.04 & 19.8 & 2.23 \\
\hline 56 & 448 & 224 & 3.70 & 0.58 & 7.32 & 2.32 & 0.17 & 2.43 & 20.7 & 1.95 \\
\hline 112 & 448 & 224 & 3.46 & 0.41 & 8.25 & 2.43 & 0.17 & 3.93 & 19.5 & 1.59 \\
\hline 168 & 448 & 224 & 3.84 & 0.64 & 7.09 & 2.30 & 0.24 & 4.28 & 21.8 & 2.55 \\
\hline 336 & 448 & 224 & $4.0 \mathrm{I}$ & 0.65 & 6.94 & 2.84 & 0.16 & 4.28 & 23.4 & 2.73 \\
\hline 168 & 0 & 224 & 3.87 & 0.52 & 7.02 & 2.50 & 0.15 & 4.00 & 23.4 & 1.72 \\
\hline 168 & 112 & 224 & 3.64 & 0.59 & 7.26 & 2.56 & 0.17 & 4.24 & 22.2 & 2.14 \\
\hline 168 & 224 & 224 & 3.93 & 0.61 & 6.39 & 2.51 & 0.17 & 4.52 & 22.1 & 2.77 \\
\hline 168 & 672 & 224 & 3.64 & 0.55 & 6.75 & 2.62 & 0.21 & 4.33 & 23.4 & 1.59 \\
\hline 168 & 448 & 0 & 3.53 & 0.56 & 7.48 & 2.40 & 0.16 & 4.20 & 25.2 & 2.63 \\
\hline 168 & 448 & 112 & 3.46 & 0.48 & 7.37 & 2.42 & 0.16 & 4.60 & 19.5 & 2.95 \\
\hline
\end{tabular}

levels on onion yields. The soil at the experimental site was classified as San Antón, Cumulic Haplustolls, fine-loamy, mixed, isohyperthermic (3).

The rainfall during the crop cycle was $42.5 \mathrm{~mm}$. Mean daily maximum and minimum temperature were 30.5 and $20.5^{\circ} \mathrm{C}$, respectively. Evaporation from a class A pan amounted to $270 \mathrm{~mm}$ from November 15, 1976 to March 17, 1977.

This experiment was laid out following a partially-incomplete block design with 12 fertilizer treatments and 5 replications. Treatment were as follows: $\mathrm{N}$ at $0,56,112,168$ and $336 \mathrm{~kg} / \mathrm{ha} ; \mathrm{P}_{2} \mathrm{O}_{5}$ at $0,112,224,448$ and $672 \mathrm{~kg} / \mathrm{ha}$; and $\mathrm{K}$ at 0,112 and $224 \mathrm{~kg} / \mathrm{ha}$ in various combinations (table $1)$.

Ammonium sulphate was used to supply $\mathrm{N}$, while $\mathrm{P}$ and $\mathrm{K}$ were supplied as superphosphate and potassium chloride, respectively. All $\mathrm{P}_{2} \mathrm{O}_{5}$ and $\mathrm{K}_{2} \mathrm{O}$ was broadcast at planting and mixed with the soil. The $\mathrm{N}$ 
was divided into two applications: one half broadcast at time of planting and mixed with the soil, and the other half banded 4 weeks later, between rows on top of the beds, and left uncovered.

Plots were $3 \mathrm{~m} \times 10.8$ with three beds per plot and two rows per bed at $30 \mathrm{~cm}$. apart. The center bed was used to obtain the experimental data and the two others were border rows. The experiment was planted on November 15, 1976, with variety Texas Grano 502. It was machine planted at $30 \mathrm{~cm}$ between rows and $7.5 \mathrm{~cm}$ between plants. The soil was treated with Dacthal W- $-75^{3}$ at the rate of $8.9 \mathrm{~kg} / \mathrm{ha}$, as a pre-emergent herbicide. ToK-E-25 was applied at the rate of $4.5 \mathrm{~kg} / \mathrm{ha}$ as a postemergent, but its effect was negligible. Shallow cultivation was also used to maintain good weed control during the experimental cycle. Overhead irrigation was supplied every other day during the germination period and during the first months of the crop cycle. From there on, irrigation was applied twice a week at the rate of $6.2 \mathrm{~cm}$ per hectare weekly up to the beginning of February, when it was discontinued to allow crop maturity.

Diazinon AG-500 at the rate of $1168 \mathrm{ml} /$ ha was used as a preventive measure especially for thrips control, since these are among the most dangerous insects attacking this crop. Also, Dithane M-45 was applied at the rate of $2.2 \mathrm{~kg} / \mathrm{ha}$ to control disease and insect damage. Kocide 101, at the rate of $2.5 \mathrm{~kg} / \mathrm{ha}$, was applied towards the end of the growing season to control bacterial damage (soft rot) by Botrytis allii.

Soil samples were taken prior to the initiation of the experiment and analyzed for $\mathrm{pH}, \mathrm{CEC}$ and exchangeable $\mathrm{Ca}, \mathrm{Mg}$ and $\mathrm{K}$ by standard laboratory methods. $\mathrm{P}$ was determined by the Olsen method from samples taken in the field prior to the application of fertilizer and also from samples taken from the broadcast plots 4 weeks after they had been fertilized. When plants were 60 days old, samples of \#3 leaves were taken and analyzed for N-P-K to determine plant nutrient levels. One week before harvest, samples of whole plants were taken to determine N-P-K and also top/bulb ratios. The youngest fully developed leaves were used for N-P-K analyses and the bulb to determine top/bulb ratios.

The experiment was harvested March 17, 1977. The crop was weighed and placed in a well-ventilated room for the curing process. Onions were classified by the standard method, i.e, a size meter. Commercial onions include those ranging from 8.7 to $5 \mathrm{~cm}$ diameter. Four classes were selected, weighed and divided as follows: Diameter of $8.7 \mathrm{~cm}, 15.3 \%$; of $7.5 \mathrm{~cm}, 32 \%$; of $6.25 \mathrm{~cm}, 30 \%$; and of $5 \mathrm{~cm}, 22 \%$. Less than $1 \%$ was discarded as culls. No disease was observed during the curing period.

${ }^{3}$ Trade names are used in this publication solely for the purpose of providing specific information. Mention of a trade name does not constitute a guarantee or warranty of equipment or materials by the Agricultural Experiment Station of the University of Puerto Rico or an endorsement over other equipment or materials not mentioned. 


\section{RESULTS AND DISCUSSIONS}

Information on some soil chemical characteristics is given in the following tabulation:

\begin{tabular}{lc}
\multicolumn{1}{c}{ Property } & Value \\
$\mathrm{pH}$ & 7.8 \\
$\mathrm{CEC}$ & $22 \mathrm{Meq} / 100$ \\
Exchangeable $\mathrm{Ca}$ & $14.3 \mathrm{meq} / 100$ \\
Exchangeable $\mathrm{Mg}$ & $5.7 \mathrm{meq} / 100$ \\
Exchangeable K & $1.8 \mathrm{meq} / 100$ \\
Available P (Olsen) & $60 \mathrm{p} / \mathrm{m}$
\end{tabular}

These data reveal that the soil is alkaline in reaction and with high fertility, as measured by exchangeable bases and P. It should be able to supply enough $\mathrm{Ca}, \mathrm{Mg}, \mathrm{K}$ and $\mathrm{P}$ necessary for crop growth.

Data on average production of onions are given on table 1. Average production of 22.0 metric tons/ha were obtained with a minimum of less than $1 \%$ culls. This is considered a high yield and points out to the potential of onion production in Puerto Rico. Mangual et al. ${ }^{4}$ reported yields of over 20 metric tons/ha for the Texas Grano 502 variety in trials at the same location.

Mean differences in yield attributable to levels of N-P-K fertilizer were not significant. The lack of response to quantities of applied fertilizer is observed when the check plots are compared with other treatments receiving various quantities of $\mathrm{N}-\mathrm{P}-\mathrm{K}$ fertilizer. Table 1 shows that nutrient levels in the check treatment at midgrowth were as high as in treatments well supplied with fertilizer. Apparently the inherent high fertility of the soil coupled to the continuous applications of fertilizer for previous sugarcane crops had raised nutrient levels to such magnitudes that they sufficed at least for one crop of onions.

In the soil samples taken prior to the fertilizer application, $\mathrm{P}$ and $\mathrm{K}$ values were of the order of 60 and $530 \mathrm{p} / \mathrm{m}$, respectively. In another set of samples taken 4 weeks after fertilization, $\mathrm{P}$ and $\mathrm{K}$ values were 63-67 and $660 \mathrm{p} / \mathrm{m}$, respectively. Plants from the check plots had as high amounts of nutrients on the leaf tissues as did plants from the fertilized plots.

Also no significant differences were measured in top/bulb ratios (table $1)$.

\section{RESUMEN}

Con el propósito de evaluar el efecto de varios niveles de N-P-K en la producción de cebolla, usando la variedad Texas Grano 502, se realizó un experimento, siguiendo un diseño de bloques incompletos parcialmente compensados, en un suelo San Antón lómico (Cumulic Haplustolls) en la finca de la Estación Experimental en Fortuna.

Los tratamientos consistieron de niveles de N-P-K aplicados a voleo antes de la siembra. El abono se aplicó sobre los bancos y se incorporó al suelo. Las parcelas consistían de 3 bancos con dos hileras de cebollas a $30 \mathrm{~cm}$ de separación y $7.5 \mathrm{~cm}$ entre plantas. De los tres 
elementos fertilizantes el P y K se aplicaron totalmente antes de la siembra. El $\mathrm{N}$ se dividió en dos partes, a saber: la mitad a voleo antes de la siembra y la otra mitad 6 semanas después, en franjas entre las dos hileras, pero sin incorporarlo al suelo.

Se obtuvo un rendimiento medio de $22 \mathrm{Tm} / \mathrm{ha}$, el cual se estima como muy bueno. No hubo diferencia significativa entre los tratamientos de N-P-K. Aparentemente el suelo San Antón en este lugar contiene suficientes nutrimentos, dada su fertilidad inherente y su largo historial de producción de caña de azúcar intensamente abonada, lo cual permite producir por lo menos una buena cosecha de cebollas.

\section{LITERATURE CITED}

1. Childers, N. F., H. F. Winters, P. R. Robles and H. K. Plank, Vegetable Gardening in the Tropics, P. R. (Mayagüez) Exp. Stn. Cir. No. 32, 144 pp. 1950.

2. Departamento de Agricultura, Puerto Rico, Anuario de Estadísticas de Puerto Rico.

3. Lugo-López, M. A. and Rivera, Luis H., Taxonomic classification of the soils of Puerto Rico, 1975, Agri. Exp. Stn. Univ. P. R., Bull. 245, 1976.

4. Knot, J. E., 1972, Handbook for Vegetable Growers, John Wiley \& Sons, Inc. New York, N. Y. $245 \mathrm{pp}$.

5. Revista de Agricultura de Las Américas, Cebollas en Grande, Extensiones, Productores Tecnificados que Compiten Mundialmente, Pag. 10-24, mayo 1977.

6. Riollano, A., Louisiana Red Creole, A Promising Onion Variety for Puerto Rico, Proc. Am. Soc. Hort. Sci. 43-272-274. 